FESIEE

Fundación Emilio Soldevilla de la Ecostigación y Desarnolio

\section{Management Letters / Cuadernos de Gestión}

journal homepage: http://www.ehu.eus/cuadernosdegestion/revista/es/

ISSN: 1131-6837 / e-ISSN: 1988-2157

\title{
SWOT analysis and GUT matrix for business management and problem solving: an application in a Brazilian case-study
}

\section{Análisis FODA y matriz GUT para la gestión empresarial y la resolución de problemas: una aplicación en un caso de estudio brasileño}

\author{
José André Villas Boas Mello*, Bruno Guimarães Jorge Pinto ${ }^{a}$, Andréa Justino Ribeiro Mello \\ ${ }^{a}$ Bachelor of Engineering. Federal Center for Technological Education Celso Suckow da Fonseca, Brazil. - brunogsf91@gmail.com - https://orcid.org/0000-0003-0014-1180 \\ ${ }^{b}$ PhD in Engineering - UFRJ. Researcher of Master's Degree in Regional Development and Productive Systems. Federal Center for Technological Education Celso Suc- \\ kow da Fonseca, Brazil. - andreajribeiro@yahoo.com.br - https://orcid.org/0000-0002-4927-960X
}

* Corresponding author: PhD in Engineering - UFRJ. Researcher of Master's Degree in Regional Development and Productive Systems. Federal Center for Technological Education Celso Suckow da Fonseca, Brazil. - joseavbm@yahoo.com.br - https://orcid.org/0000-0002-0628-9664

\section{A R T I C L E I N F O}

Received 09 April 2021,

Accepted 13 September 2021

Available online 10 February 2022

DOI: $10.5295 / \mathrm{cdg} .211472 \mathrm{jv}$

JEL: L92, D12

\begin{abstract}
A B S T R A C T
The present research aims to use SWOT analysis to identify strategic problems of small business companies (SBCs) from the automotive selling parts of a brazilian city and use the GUT matrix for identifying a Priority Level (PL) result of each problem listed. This case-study is expected to bring improvements to the automotive pole in territory, as a way to quantify and prioritize the actions focused on the weaknesses and threats identified though the SWOT analysis (an acronym for strengths, weaknesses, opportunities, and threats and is a structured method that evaluates those four elements on a strategic way), the GUT matrix (technique for priorization and decision making) will be used according its aspects of severity, urgency and tendency. It finds that solving problems of "Low cooperation between the companies" and increase the level of interaction between the companies will increase generation of information. Solve "infrastructure deficiency and accessibility to the Pole" problems will increase the Association's recognition and representativeness, bringing closer and enabling the gradual implementation of a more adequate governance.
\end{abstract}

Keywords: SWOT Analysis, GUT Method, Local Productive System, Entrepreneurs, Nova Iguaçu, Management.

R E S U M E N

La presente investigación tiene como objetivo utilizar el análisis FODA para identificar problemas estratégicos de pequeñas empresas (SBC) relativos a la venta de automóviles en una ciudad brasileña, y utilizar la matriz GUT para identificar un resultado sobre el Nivel de Prioridad (PL) de cada problema enumerado. Se espera que este caso de estudio traiga mejoras al polo automotriz en el territorio, de tal manera que se cuantifiquen y prioricen las acciones centradas en las debilidades y amenazas identificadas a través del análisis FODA (acrónimo de fortalezas, debilidades, oportunidades y amenazas, el cuál es un método estructurado que evalúa esos cuatro elementos de manera estratégica), y se utilice la matriz GUT (técnica de priorización y toma de decisiones), según aspectos de severidad, urgencia y tendencia. Se considera que resolver problemas de «Baja cooperación entre las empresas» y aumentar el nivel de interacción entre las empresas aumentará la generación de información. Por otro lado, resolver los problemas de «deficiencia de infraestructura y accesibilidad al Polo» aumentará el reconocimiento y la representatividad de la Asociación, acercando y posibilitando la implementación paulatina de una gobernanza más adecuada.

Palabras clave: Análisis FODA, Método GUT, Sistema Productivo Local, Emprendedores, Nova Iguaçu, Gestión. 


\section{INTRODUCTION}

Under an unfavorable economic scenario, with the increase of interest rates, high inflation and exchange rates, political instability (Hartmann 2016; Ahadi and Kasraie 2020), fall in the consumer confidence indicators, difficulty to acquire credit and forecasts (Ivo et al. 2016; Lima e Martini 2016). For the future not so optimistic due to the strong political crisis, the number of unsuccessful small companies might suffer a significant increase (Eberhart et al. 2017), if the organizations are not able to see and understand the strategic planning process (Rolleri et al. 2016).

The new globalized world, with interconnected markets, obliges organizations to invest in competitiveness and continual improvement (Batista and Santos 2015; Carrol and Helfert 2015). The inter-organizational cooperation helps in the acquisition of competitiveness factors, such as: consumer market proximity, innovation generation (Camisón and Villar-López 2014), access to resources (Rodríguez et al. 2016), plus to organizational and infrastructure improvement (Kalkman and Waard 2017).

The dynamics of organizational configurations in the territory can indicate the existence of incipient and inconsistent interorganizational links towards more integrated relations (Barros and Moreira 2006; Ribeiro et al. 2020). Some studies such as Galindo et al. (2011), Cabrera et al. (2017), Jacometti et al. (2016), shows how the cooperation model is applied and beneficial. In our research we did not find studies that provide a strategic apply to production system companies of automotive parts sales, specifically studies on the state of Rio de Janeiro/Brazil, and the city of Nova Iguaçu, a peripheral municipality that develops great territorial centrality.

The present research aims to use SWOT analysis to identify strategic problems of small business companies (SBCs) from the automotive selling parts of a brazilian city and use the GUT matrix for identifying a Priority Level (PL) result of each problem listed. Through the use of SWOT and GUT tools, it is hoped to propose actions to local development. The combination of SWOT and GUT tools provide opportunities to identify and prioritize, a combination of decision-making processes that enhance competitiveness. Damazio (1998) and Costa et al. (2017) says that the GUT technique is used to prevent the mixture of problems from generating confusion, that is, when the problems are several and related to each other. Marshall Junior et al. (2006) and Carvalho and Castro (2020) corroborate by stating that the use of the GUT matrix serves to prioritize and analyze.

The use of a GUT matrix as an application of SWOT allows to quantify decisions. Then, the study becomes relevant to qualify decision making process, corroborating with Ceretta and Froemming (2015) that point out to the need of having cities developed, because it attracts new investors and buyers, making the territory favorable to the consumption and profitability.

After this introduction, a bibliographic review section was presented. Following is a section on methodology and results, one with the results and swot and GUT matrices. Finally, present a section with the conclusions and references.

\section{BIBLIOGRAPHIC REVIEW}

The bibliographic review starts with the characteristics of small companies and the planning process, a necessary review in order to show how is the standard behavior of organizations with the typical profile of those considered in this study. Then advances to explain the SWOT and GUT tools.

\subsection{Characteristics of the small companies planning}

One of the first steps to elaborate a strategical planning is to understand that small companies have particularities that affect their way of operation and that they need a differentiated management process, and consequently, a differentiated strategical process. According to Souza and Qualharini (2007), a planning process with the adequate approach should take into consideration the following characteristics:

- Very limited resources;

- Organizational structure tend to be very simple and it is not always clearly defined;

- Lack of a long-term vision;

- Control systems are usually informal;

- Reduced number of hierarchic levels e the centralized decisions;

- Limited access to technology;

- Insufficient access to working capital sources and technological innovations;

- Recruiting and maintenance of qualified workers is usually very difficult;

Understand the reality and changes of the environment can increase the capacity for innovation and to respond efficiently to existing challenges, with their capacities and talents, in a permanent process of learning (Bezerra and Schlindwein 2017). Such priorities are present in the organization's structural and infrastructural decisions, with a greater emphasis on infrastructural decisions, activities linked to the day-to-day (Silva et al. 2020). Terence and Filho (2001) go beyond and affirm that the particularities in the management process of these companies that must be considered are divided in three aspects: behavioral, structural and contextual.

The first one is related to personal aspects of the entrepreneur himself, reflecting his values, ambitions, ideologies, vision and behavior. Referring, in a general way, to the individualism and conservatism, centralization of power, tendency of becoming obsolete, lack of time management and the ability to improvise regarding a planned action. Miao et al. (2016) cite that the individualistic culture lacks the environment capable of delivering results. Under the collectivist culture, the performance relationship will be strengthened due to fewer constraints.

The second refers to the internal aspects resulting from the way the company is organized. In this category are: informality in the relations in the company, reduced and informal organizational structured, lack of resources and qualified personnel, inadequate or lack of use of management techniques and tools.

The third is related to the external environment of the company and it is not controllable by the actions of the executive leaders. The following are considered contextual particularities: lack of information regarding the evolution of the market and its products, difficul- 
ty to access management processes training and funding sources for new projects, lack of analysis about the market and its way of acting.

In order to support the planning process, the use of strategical tools is very common. There are several tools that can facilitate the managers' decision making process, each day more these managers are seeking to use these tools to keep themselves competitive in the market. Leal and Queiroz (2020) mention that the decision-making process is complex and there are several factors that interfere in decision making, making rationality and logic not always the primary elements in the choice method.

\subsection{SWOT AND GUT tools as a support to the planning process}

Two tools have been used more frequently to support the formulation process of the strategical planning: SWOT analysis and GUT matrix. The first, used to analyze and compose the diagnosis of the internal and external environment. The second to sustain the strategies formulation, objectives definition and prioritization of the actions to be implemented.

\subsubsection{SWOT ANALYSIS}

The formulation of the environment diagnosis included the analysis of the internal and external factors to the organizations, capable of influencing the decision making process and their way of operating in the market.

The environment analysis also called SWOT analysis is a tool used to realize and analyze different scenarios or places, being mostly used as a basis to strategic planning and management of an organization (Daychouw 2007). Analyzing the external environment consists in identifying opportunities and threats outside the organization. The internal environment of a company is composed by variables such as: strengths and weaknesses or strong and weak points, existent inside the organization itself (Halili 2020).

\subsubsection{External environment analysis}

The analysis of the external environment is aimed to study the relation between the organization and its environment regarding opportunities and threats existent. It is based on the activity of evalutation and interpretation of the main environmental factors that might affect the organization and how the evolution of these factors might impact the operations in a near future. In general, it is not possible to control these external factors, however, it might be possible to exercise some kind of influence on them.

According to Oliveira et al. (2001), opportunities are conditions resulting from the external and uncontrollable variables that might create favorable circumstances to a good performance, as long as there are concrete ways and the desire to take advantage of these circumstances. Threats are conditions created by external and uncontrollable variables that might result in circumstances that are unfavorable to the performance of an organization's institutional mission.

\subsubsection{Internal environment analysis}

The internal analysis of the organization consists in a systemic and methodic effort of deepening and enhancing its internal elements. An effort focused pure and simply on enhancing the knowledge of the organization itself, gathering information regarding its performance, coworkers, products, services, structural organization, clients and suppliers.

It contemplates the identification of weaknesses and strengths. According to Oliveira et al. (2001) and Szum and Nazarko (2020), the strengths or strong points are internal and controllable variables, which provides favorable conditions to the organization related to the competition environment. Weaknesses or weak points are those responsible for an unfavorable situation related to the same environment or they tend to unbalance it, turning the decision making process even more difficult, compromising the future of the organizations.

After the internal and external environment analysis, it is possible to consolidate the information, enabling the reader to have an objective and clear vision about what are the internal weaknesses and strengths of the organization and what are the opportunities and threats in the external environment, making it possible to cross information, analysis and elaborating strategies.

\subsubsection{GUT ANALYSIS}

The GUT (Gravity, Urgency and Tendency) Matrix of Kepner and Tregoe (1981) is a method used to prioritize the decision making, a tool that is used by several Brazilian organizations (Silva et al. 2017). The use of this tool inspires several Brazilian researchers to use on their researchs this prioritization matrix connected with other tools. Brazilian authors for exemple, Melo (2017), Costa et al. (2017), Carvalho and Castro (2020), among other, presents a view that this tool has an advantage in terms of the objectivity and simplicity of application, which makes it easy to identify which difficulties must be solved first.

It is possible to say that the GUT matrix is quite similar to the SWOT analysis, and therefore one complements the other, because both of them are able to analyze the internal and external environments of an organization. The only difference is that with the matrix, we are able to quantify information and score the analysed items according to their priority level.

The GUT matrix presented by Kepner and Tregoe (1981), also known as prioritization matrix, is a tool widely used by the companies. According to Meireles (2001), it is used to define priorities given several alternatives of action, in order to prioritize problems and consequently treat them, taking into consideration the severity, urgency and tendency of these problems.

This tool is very effective to manage problems inside a company, even though it is quite simple, because it enables a quantitative and qualitative assessment, providing consistent number with a specific priority level. Thereby, it is possible to prioritize corrective and preventive actions that might reduce or eliminate problems.

To create the matrix it is necessary to list all the problems and aspects related to the segment analysed. The main problems or deficiencies existent in the organization should be listed taking into consideration three parameters, called G.U.T.: gravity, urgency and tendency. In the initial step, it is very important to be specific and describe the aspects in a clear and objective way, in order to avoid inadequate and confuse interpretations. Regarding the parameters utilized in the matrix, they are considered as: 
- Gravity or Severity - possible damage or loss that might incur as an outcome of a situation addressed incorrectly, for example: what would be the impact of a training or recycling course that was not attended by a team that performs high risk operations?

- Urgency - related to the time available to correct or resolve a given situation or a given problem, for example: the need of a training or recycling course is something required by law with defined deadline, however, there is a forecast indicating a possible change in the legislation making these due dates even shorter, increasing the urgency to solve this situation so there will not be any further complication.

- Tendency - pattern or tendency to escalate the situation, for example: if the training or recycling course is not concluded on time, will the performance of the team during the execution of the high risk operation be affected? Is there a tendency of worsening the situation?

After the initial step of listing the problems or the analysis points, it is necessary to score each and every one of these problems according the three parameters informed previously. According to Behr et al. (2008), the grades of each problem shall be weighted according the situations that can go from not favorable or most severe (grade 5) to most favorable or light weight (grade 1) as shown in the Table 1.

Table 1

Qualitative factors to create the GUT matrix

\begin{tabular}{|c|c|c|c|}
\hline Level & Gravity / Severity & Urgency & Tendency \\
\hline 5 & Extremely severe & Extremely urgent & $\begin{array}{l}\text { Will worsen } \\
\text { immediately }\end{array}$ \\
\hline 4 & Very severe & Very urgent & $\begin{array}{l}\text { Will worsen in a } \\
\text { short-term }\end{array}$ \\
\hline 3 & Severe & Urgent & $\begin{array}{l}\text { Will worsen in a } \\
\text { medium-term }\end{array}$ \\
\hline 2 & Low severity & Low urgency & $\begin{array}{l}\text { Will worsen in a } \\
\text { long-term }\end{array}$ \\
\hline 1 & Without severity & Without urgency & $\begin{array}{l}\text { Without tendency of } \\
\text { worsening }\end{array}$ \\
\hline
\end{tabular}

Source: Behr (2008).

At the end of the scoring process, there will be an identification of the index that will be the priority level of the problems. To this end, the values allocated in each severity, urgency and tendency parameter of the matrix should be multiplied, and the item with the highest result, should be the main priority to be addressed.

In the end, after listing all the problems, scoring, assigning grades e prioritizing activities, it is necessary to elaborate an action plan, taking into consideration each aspect of the matrix and the final classification.

\section{RESEARCH METHODOLOGY}

This is a descriptive and explanatory research. Descriptive, because it aims to describe the environment, internal and external, of the companies inside the Automotive Pole of Nova Iguaçu, exposing their actual management characteristics and orientation, identifying needs, deficiencies and possible difficulties that these organizations might be facing. Exploratory, because it has the objective to clarify some factors that contribute to the occurrence of determined phenomena that might be correlated to the problems found and faced by these organizations and mitigated through the use of tools, techniques and strategical plans.

Regarding the means, we can classify it as exploratory through a case study that apply a survey for the construction of the study's base theory. Exploratory, because it is intended to apply and study the influence of unknown tools or not yet utilized in the organizational environment mentioned, where there is not any accumulated and systematized knowledge. And a case study, because an empirical investigation is performed on the local where primary data is collected form the companies that are part of the local productive system of the brazilian city.

The data are collected through structured and semi structured interviews, questionnaires and non-participating observations. Gomes et al. (2016) says that the theoretical framework used to develop the analysis of the results focuses on market structures, strategies and effects on performance as recommended by the School of Industrial Organization.

As a way to quantify and prioritize the actions focused on the weaknesses and threats identified though the SWOT analysis (an acronym for strengths, weaknesses, opportunities, and threats and is a structured method that evaluates those four elements on a strategic way), the GUT matrix (technique for priorization and decision making) will be used according its aspects of severity, urgency and tendency. The combined use of the matrices will help answer the following questions: Where should the organizations direct their efforts to? Which problems should be prioritized?

\subsection{Data collection techniques}

The data collection involved to this kind of study, requires in loco visits and interview with the owner of the microbusiness enterprise (Oliveira et al. 2017). To collect the necessary data to apply the tools to promove local development to case study: structured and semi structured interviews were conducted in order to acquire a general view of the management of the SBCs in the Automotive pole and its Association, understand how the planning process works, if it actually exists, how the management works, which type of problem solving tools are used and applied on the actor daily routine, what are the benefits and challenges faced by the managers of the studied organizations.

The local development depends on the capacity of local actors (Carvalho et al. 2020; Babalola and Jagede 2020). A first interview, structured and informal, was conducted with the person responsible for the Association of the Automotive pole of Nova Iguaçu. A script of questions was used to guide the interview where the main objective was to obtain information about the appearance of the Pole and its Association, know what services are offered to the companies, the levels and types of control that are exercised, which resources are considered the most important, what are the deficiencies and difficulties most common found in the daily routine.

Afterwards, a second block of informal and semi structured interviews were conducted with the entrepreneurs, directors and managers of the auto parts stores associated, formally or not, to the Automotive pole. These interviews were responsible for validating the information gathered on the first interview and to collect new information concerning the characteristics and 
specificities on the internal aspects of these organizations, such as: management, actual strategies, tools and planning techniques and the operational difficulties found during the work routines.

Approximate universe of 40 businessmen in one central street. Initially, in phase 1,6 people were interviewed: 1 responsible for the Association of the Automotive pole and 5 other responsible directly or indirectly for a total of 9 stores. The collected information was validated by expert judges. With this exploratory data, became possible to construct a matrix itens. In phase 2, after the information was gathered during the interviews, closed questionnaires were applied on site to a quantitative number of companies, totalizing 21 respondents, as a method of quantifying the priority levels the GUT matrix was elaborated. The data collection of this research was performed between the months of April and May of 2016.

\subsection{Data analysis procedure}

The data gathered for this research are essentially provided by third parties, taking into consideration the understanding, interpretation, qualification and thoughts on the inquiries and questions done through the interviews and the questionnaire application. The SWOT analysis and GUT matrix were used to analyze the data.

Regarding the interviews, as a way of mitigating these variables, was assured that all the interviewed personnel were qualified inside their organization and that they had total knowledge about the subjects approached during the questions and their respective objectives, making the interviews flow in an objective and cohesive way. Regarding the questionnaires, they were required to be fulfilled by people responsible for the operational routine of the company and with a general view of the business.

The analysis of the data collected during the interviews is given in a qualitative way concerning the interpretation and passage of the information acquired. The information was used to elaborate the SWOT analysis, helping to construct the actual scenario through the internal and external environment analysis of these organizations.

The GUT matrix was then used to prioritize the problems found in the SWOT analysis. The analysis of the score after the application of the questionnaires to the responsible people for the companies was made in a quantitative way, where the item with the highest score represented the most critical among those listed.

\subsection{SWOT Matrix}

Based on the data collected during the interviews, the analysis of the internal and external environment of the organizations inside the Pole and the field observations, the elements of the SWOT matrix were defined and will be used subsequently in the GUT matrix, such as:

Strengths: The solidness of the organization; Belief in the associative process; Representativeness of the Pole in the local economy; Plurality and quality of the products and services; Low operational cost; Quality customer service;

Weaknesses: Physical distance of the owners/entrepreneurs; Lack of flexibility in the management; Deficient stock management; Lack of communication of the strategical decisions to the workers;

Opportunities: Increase the partnerships between companies and universities; Innovate in products and services;
Threats: Low cooperation between companies; Fall of customers' purchase power; Infraestructure and accessibility to the Pole; Low availability of parts; Demand for parts and services for imported vehicles.

\subsection{GUT matrix construction}

The following points to be analysed were found during the SWOT analysis and will be listed as a problem in the matrix:

- Lack of a structured buying process

- Deficient stock management

- Faulty internal communication

- Lack of management flexibility

- Low cooperation between companies

- Low availability of parts and equipments

- Deficiency in the infrastructure and accessibility to the Pole

- Increase of the demand for imported parts

The topics: "physical distance of the owners/entrepreneurs" and "fall of customers' purchase power" won't be listed in the matrix as a problem. The first one, by the fact that it is only a geographic matter and there will not be any action or suggestion that could be implemented in a practical way, that way the aspects of gravity, urgency and tendency will not be relevant for an analysis. The second one is about a macroeconomic aspect, although it exercises a huge influence in the retail market, there will not be any possible measures to be taken by the organization that might mitigate or revert this problem. The final score of each problem in the matrix will be calculated through a weighted average $\mu$ of the total score of each item for the aspects of severity, urgency and tendency, utilizing the Equation 1:

$$
\mu=\Sigma x / N
$$

Where:

$x=$ individual score of the problems

$N=$ number of individuals

The Prioritization Level (PL) of each problem listed in the matrix was calculated through the product of the final score of each aspect, as shown on the Equation 2:

$$
P L=G \times U \times T
$$

To calculate and obtain the final score of each individual problem, closed questionnaires were applied to the representatives of the SBCs inside the Automotive Pole as defined in the research methodology.

\section{RESULTS}

\subsection{Research universe}

In Figure 1 the Nova Iguaçu city, a Brazilian municipality, the Association of the Automotive pole of Nova Iguaçu, entity responsible for the development of the local entrepreneurs of companies from the automotive sector, have more than 30 SBCs associated. 


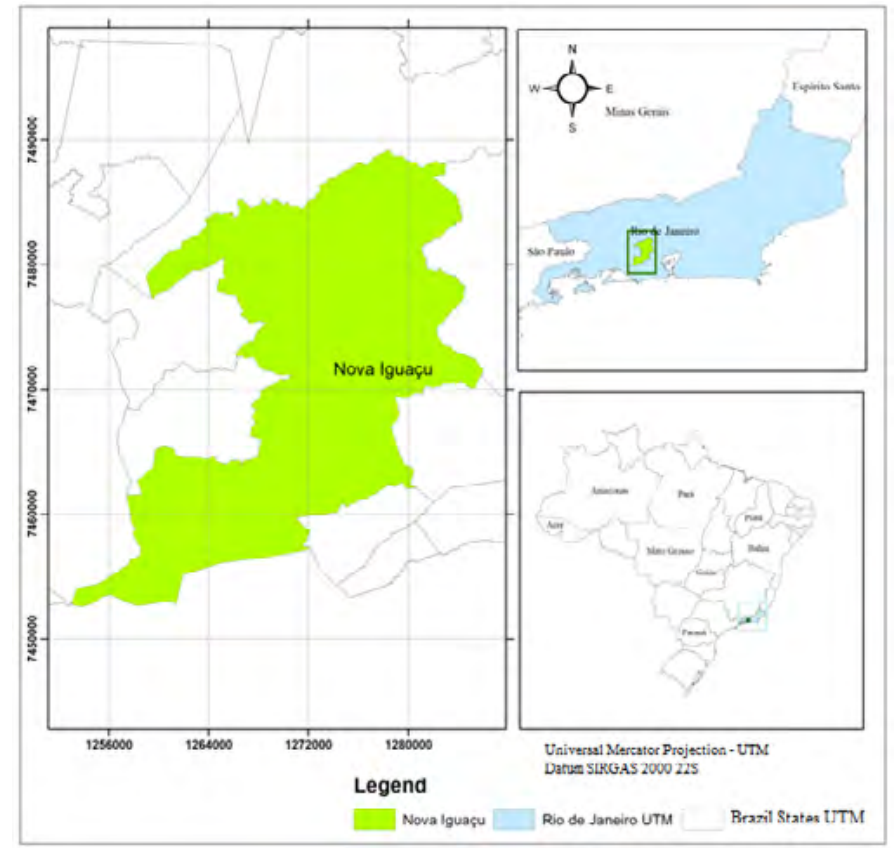

Figure 1

Nova Iguaçu city location
The universe of the research is limited by the companies from the auto part segment that are located inside the Automotive pole, formally associated or not, that are responsible only for the automotive parts and equipments sales and do not offer parallel services involving the products sold or any type of maintenance of vehicles inside the physical store.

This study's sample is the not probabilistic type, selected by accessibility, because the questionnaires were applied according to the ease geographically access. There are two sample types utilized to apply questionnaires according to Vergara (2010): probabilistic, it is based in statistical procedures that might be simple random, stratified or by conglomerate; and the not probabilistic, selected by accessibility or typicality.

The Automotive arrangement is delimited by the streets Dr. Luiz Guimarães, Otávio Tarquino and the Nilo Peçanha Avenue, located in the commercial center of Nova Iguaçu, between the Presidente Dutra Highway and Via Light, housing more than 120 SBCs offering national and international products and services from the automotive sector, generating a great number of direct and indirect jobs. Figure 2 allows us to have a visualization of the space composed by the pole.

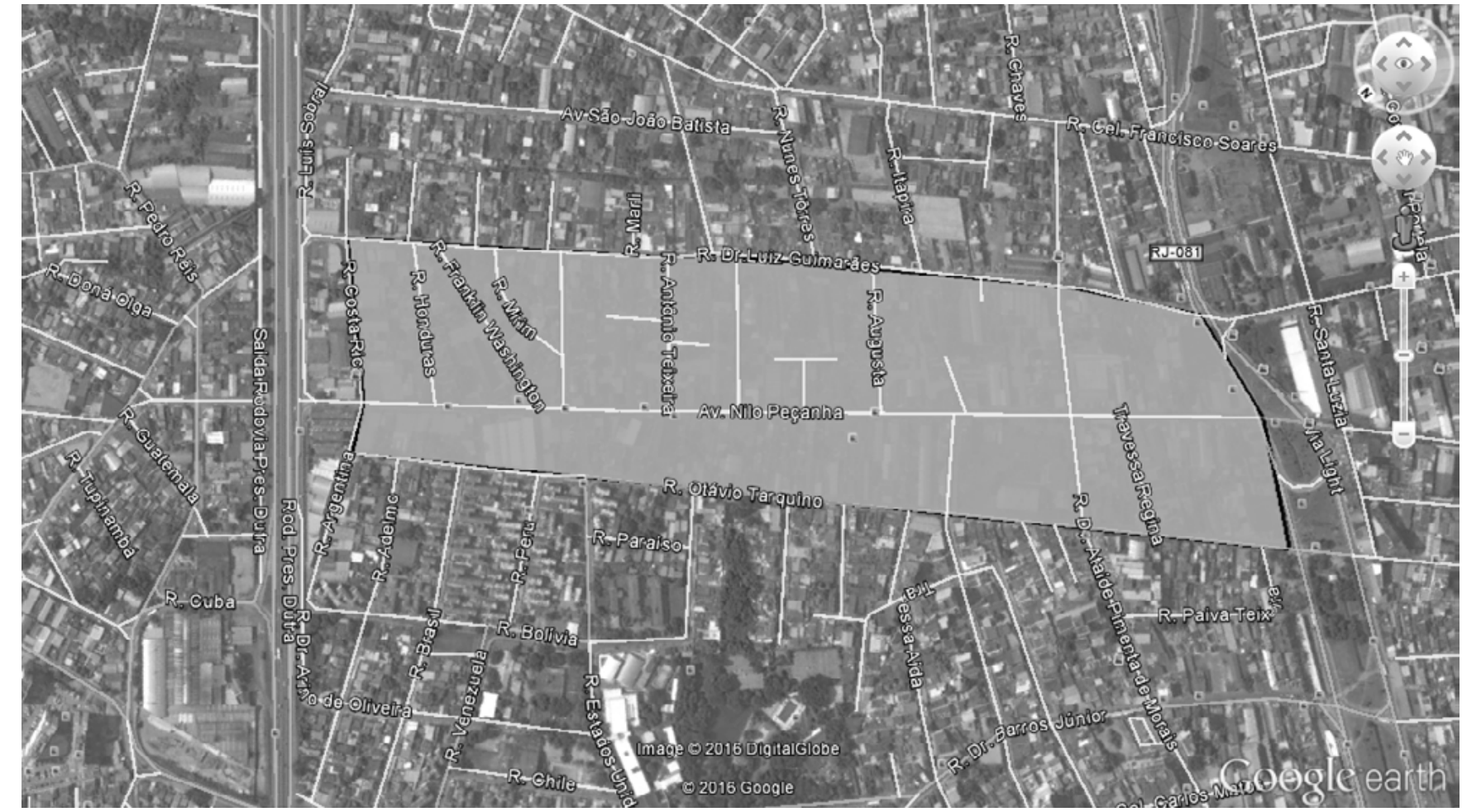

Figure 2

Representation of the geographic space of the pole Source: GOOGLE EARTH.

At a first moment, the interviews were conducted with the local representatives of SEBRAE. Afterwards, with the directors, managers and owners of the stores located in the Pole to have a better understanding of what are the main role of these compa- nies inside the arrangement, the management type, the strategies that guide them and what are the benefits and difficulties of being inside a productive system, enabling the analysis of the internal and external environment of these companies. 
These data were collected during the interview and were used to construct the actual scenario of the auto parts local market and to feed and validate the strategic tools used, that in the end, gave shape to the questionnaire that was later applied to the responsible personnel of the studied companies enabling the elaboration of suggestions and an action plan.

Every information captured was utilized to reach the general and specific objectives of this research as well as to answer the key questions of this study and obtain its respective conclusions. The first and second steps allowed the formulation of the SWOT analysis through the external and internal environment diagnose of the organizations, taking into consideration the organization as an individual and actively actor inside the Automotive Pole.

As shown in the Table 2, five people were interviewed with different profiles and forms of action inside their organizations. The subjects approached during the interviews were: general aspects about the participation of the companies inside the local productive system, such as: competitiveness, opportunities, positive and negative points; perspectives for the future of the auto selling parts segment in the local market; the role of the Association as a facilitating agent inside the Automotive pole; forms of internal organization.

Table 2

Profiles of the interviewed in phase 1

\begin{tabular}{|c|c|c|}
\hline Interviewed & Profile & Association status \\
\hline Number 1 & $\begin{array}{l}\text { Entrepreneur responsible for } \\
3 \text { auto parts store with a great } \\
\text { representativeness inside the } \\
\text { Automotive pole, each store with a } \\
\text { number of } 5 \text { to } 10 \text { workers. }\end{array}$ & Associated \\
\hline Number 2 & $\begin{array}{c}\text { Partner-manager of one auto } \\
\text { parts and services store with } 5 \text { to } \\
10 \text { workers and participant in the } \\
\text { society of other } 2 \text { stores of the same } \\
\text { segment. }\end{array}$ & Associated \\
\hline Number 3 & $\begin{array}{l}\text { Commercial manager responsible for } \\
\text { the sales department of an auto parts } \\
\text { store with } 5 \text { workers maximum. }\end{array}$ & Non-associated \\
\hline Number 4 & $\begin{array}{l}\text { Partner-director of an auto parts } \\
\text { store with } 5 \text { workers maximum and } \\
\text { responsible for the management of } \\
\text { another store. }\end{array}$ & Associated \\
\hline Number 5 & $\begin{array}{l}\text { Owner of an auto parts store with a } \\
\text { number of } 5 \text { to } 10 \text { workers. }\end{array}$ & Non-associated \\
\hline
\end{tabular}

Source: Author's elaboration.

Even though the fact that the number of interviews was considered low in comparison with the total number of existent store in the arrangement and that the interviewed personnel exercise their roles in different ways, their stores have a great representativeness inside the Pole, which enables the results to be interpreted as valid related to the sampling studied, but do not bring conclusions for the theme of strategical planning in a general manner for every and each kind of local productive system.

\subsection{Analysis of the internal and external environment of the companies inside the arrangement}

The way a company is managed, the strategic direction that guides all of its actions, even though it is wide and might contain few details about the management and operational aspects inside the company, it tends to be really individual and contemplates specially the objectives, vision and goals of that company in question. This way, to perform the internal and external analysis that might include all these different organization inside the same productive system, analysis points common to every organization were raised in a general manner, eliminating each and every characteristic or specificity that might by exceptional to any of them, reaching a higher number of organizations with this analysis.

During the interviews, was possible to perceive the solidity of their organizations, with clear objectives and goals, as well as the certainty that their main activity have a huge importance, not only in the auto parts retail market, but in the whole community that they are inserted. However, the internal communication between employers and employees is not given in an efficient and effective way, maybe because the the interviewed personnel lacked qualification regarding human resources management or by a certain resistance in including the workers in the organizational context making available a higher amount of information to them. Some of them say that the physical distance of the managers is a limiting factor to keep them closer.

All the 5 interviewed acknowledge the representativeness of the Pole inside the local economy, the importance of forming partnerships, not only with other companies, to communicate externally and believe that the associative process brings benefits to both sides, however, the interviewed number 3 and 5 affirm not being associated formally because they do not need the services offered by the Association today and that the types of services offered are very limited. Most of them believe that the Association should make themselves more present in terms of infrastructure and accessibility to the Pole, pleading improvements along the Government and representative entities.

A strong characteristic of the business explored by the interviewed is the diversity and quality of the products and services offered, concentrating great parts of the final customers in one plane. Another characteristic is the focus on customer service quality, bearing in mind that a great number of workers in the companies studied have passed through a training offered by the Association. The increase in the demand for imported parts by the customers has been perceived by a great part of the interviewed, and two of them (number 1 and 2) affirm that they already have imported parts in their portfolio, despite its difficult access. Regarding the operation cost of these companies, the fact that the suppliers perform combined deliveries directly on the companies and their stock houses that are also concentrated, makes their operational cost relatively low.

It is possible to affirm, based on the information collected during the interviews, that every company is directed by results oriented strategy, where the main objective is the total customer satisfaction, through the commercialization of different products and services and the good customer services. However, the lack of participation of the workers in the organizational envi- 
ronment interfere their performance, because besides the training offer by the Association, their employers do not invest time nor financial resources in training, such as sales techniques, negotiation and etc.

The lack of a systemic view of the business and the understanding that each and every worker is an important part of an organization, capable of leveraging the profitability of the company if they are trained, motivated and used correctly. This could be considered a faulty point inside these organizations. These characteristics are not limited to the environment of a single company, it was observed in the 5 companies, and therefore, the execution of a strategy focused on the results and also to the qualification of the managers would bring considerable benefits to both, employer and employee.

\subsection{Results analysis in phase 2}

The results analysis consists in the presentation and consolidation of the information obtained with a questionnaire application, obtaining the prioritization level of each problem listed in the GUT matrix as well as the final analysis exposing the positive points found in the SWOT analysis.

\subsubsection{Demographic DATA}

The demographic data of this research are presented in the Table 3 , with the information of the 21 respondents related to their gender, age, position or function, area of action and professional experience time. Most of them are male, corresponding to $76 \%$ of the valid sample. Regarding the age, prevails those between the age of 26 to 35 years (38\%) and 36 to 45 years (24\%). As for the position or function, the manager position is the predominant, responsible for $52 \%$ of the sample. A great part of the respondents act in the commercial area, totalizing a percentage of $62 \%$. The professional experience time of most of the respondents were divided between 11 to 20 years (38\%) and above 20 years (38\%).

The objective of the Table 3 is only to present the profile of the respondents, however, there are a few relevant points that should be highlighted. The predominance of the male gender $(76 \%)$ is given because companies are inserted in the automotive segment, and the number of women, especially in a management position, is still lagged in comparison with the number of men in the same position.

Regarding the positions, there are a great number of managers, most of them working in the commercial area, this is given for the fact that most of the owners are distant physically, making these managers totally responsible for the daily operational routine. The presence of a respondent classified as others, was due to the absence of a manager in the store at the moment the questionnaire was applied.

Every participant company in the research has as a main activity parts and automotive equipments sales, therefore the management that is the most demanded in terms of activities and tasks is the commercial one, which is why $62 \%$ of the respondents are from the commercial area. The ones that are classified as others (4\%), is because the owners guarantee that they assume multiple functions in the commercial, financial and administrative area because they need to or the lack of qualified workers.
Table 3

Demographic data

\begin{tabular}{|c|c|c|c|}
\hline Type of data & Characteristics & Quantity & $\%$ \\
\hline \multirow{2}{*}{ Gender } & Female & 5 & $24 \%$ \\
\hline & Male & 16 & $76 \%$ \\
\hline \multirow{4}{*}{ Age } & Less than 26 years & 4 & $19 \%$ \\
\hline & From 26 to 35 years & 8 & $38 \%$ \\
\hline & From 36 to 45 years & 5 & $24 \%$ \\
\hline & Over 46 years & 4 & $19 \%$ \\
\hline \multirow{5}{*}{ Age } & Supervisor / Coordinator & 0 & $0 \%$ \\
\hline & Manager & 11 & $52 \%$ \\
\hline & Director & 5 & $24 \%$ \\
\hline & Owner & 4 & $19 \%$ \\
\hline & Others & 1 & $5 \%$ \\
\hline \multirow{4}{*}{ Professional experience } & Less than 5 years & 3 & $14 \%$ \\
\hline & From 6 to 10 years & 2 & $10 \%$ \\
\hline & From 11 to 20 years & 8 & $38 \%$ \\
\hline & Over 20 years & 8 & $38 \%$ \\
\hline \multirow{4}{*}{ Area of action } & Administrative & 4 & $19 \%$ \\
\hline & Commercial & 13 & $62 \%$ \\
\hline & Financial & 0 & $0 \%$ \\
\hline & Others & 4 & $19 \%$ \\
\hline
\end{tabular}

Source: Author's elaboration.

\subsubsection{Frequency Regarding the aspects of SeVerity, URGENCY AND TENDENCY - GUT}

Despite the scoring methodology of the matrix is based in the weighted average of the individual score of each problem, it is important to point out the result obtained in terms of frequency of the answers regarding each aspect presented in the matrix, shown in the tables below, so it is possible to analyze and identify the possible standards existent in the answers.

The Table 4 presents the frequency of the answers obtained on each problem listed in the GUT matrix after the questionnaire application, taking into consideration the severity aspect. It is possible to notice that there is a higher percentage of answers in the left side, with 6 from the 8 problems appearing with a frequency higher than $30 \%$ under the same level 1 of severity ("without severity").

Table 4

Frequency of the answers regarding the aspect of severity

\begin{tabular}{lcccccc}
\hline \multirow{1}{*}{ Problems } & \multicolumn{5}{c}{ Severity aspect } \\
\cline { 2 - 7 } & $\begin{array}{l}\text { Without } \\
\text { severity }\end{array}$ & $\begin{array}{c}\text { Low } \\
\text { severity }\end{array}$ & Severe & $\begin{array}{c}\text { Very } \\
\text { severe }\end{array}$ & $\begin{array}{c}\text { Extremely } \\
\text { severe }\end{array}$ & Total \\
\hline $\begin{array}{l}\text { Lack of } \\
\text { structured } \\
\text { buying process }\end{array}$ & $38 \%$ & $14 \%$ & $19 \%$ & $10 \%$ & $19 \%$ & $\mathbf{1 0 0} \%$ \\
$\begin{array}{l}\text { Deficient stock } \\
\text { management }\end{array}$ & $29 \%$ & $19 \%$ & $10 \%$ & $19 \%$ & $24 \%$ & $\mathbf{1 0 0} \%$ \\
\hline
\end{tabular}




\begin{tabular}{|c|c|c|c|c|c|c|}
\hline \multirow[b]{2}{*}{ Problems } & \multicolumn{6}{|c|}{ Severity aspect } \\
\hline & $\begin{array}{l}\text { Without } \\
\text { severity }\end{array}$ & $\begin{array}{c}\text { Low } \\
\text { severity }\end{array}$ & Severe & $\begin{array}{c}\text { Very } \\
\text { severe }\end{array}$ & $\begin{array}{l}\text { Extremely } \\
\text { severe }\end{array}$ & Total \\
\hline $\begin{array}{l}\text { Faulty internal } \\
\text { communication }\end{array}$ & $52 \%$ & $0 \%$ & $29 \%$ & $5 \%$ & $14 \%$ & $100 \%$ \\
\hline $\begin{array}{l}\text { Lack of } \\
\text { management } \\
\text { flexibility }\end{array}$ & $43 \%$ & $19 \%$ & $19 \%$ & $0 \%$ & $19 \%$ & $100 \%$ \\
\hline $\begin{array}{l}\text { Low cooperation } \\
\text { between } \\
\text { companies }\end{array}$ & $24 \%$ & $14 \%$ & $24 \%$ & $10 \%$ & $29 \%$ & $100 \%$ \\
\hline $\begin{array}{l}\text { Low availability } \\
\text { of parts and } \\
\text { equipments }\end{array}$ & $33 \%$ & $10 \%$ & $24 \%$ & $5 \%$ & $29 \%$ & $100 \%$ \\
\hline $\begin{array}{l}\text { Deficiency in the } \\
\text { infraestructure } \\
\text { and accessibility } \\
\text { to the Pole }\end{array}$ & $33 \%$ & $14 \%$ & $10 \%$ & $14 \%$ & $29 \%$ & $100 \%$ \\
\hline $\begin{array}{l}\text { Increase of the } \\
\text { demand for } \\
\text { imported parts }\end{array}$ & $48 \%$ & $24 \%$ & $10 \%$ & $0 \%$ & $19 \%$ & $100 \%$ \\
\hline
\end{tabular}

Source: Author's elaboration.

In the Table 5, it is possible to see the frequency of answers related to the aspect of urgency. With only 3 of 8 problems presenting a distribution less heterogeneous (deficient stock management, low cooperation between companies and low availability of parts and equipments), becomes clear that most of the answers are concentrated under the level 1 or urgency ("without urgency").
Table 5

Frequency of the answers regarding the aspect of urgency

\begin{tabular}{|c|c|c|c|c|c|c|}
\hline \multirow[b]{2}{*}{ roblems } & \multicolumn{6}{|c|}{ Urgency aspect } \\
\hline & $\begin{array}{l}\text { Without } \\
\text { urgency }\end{array}$ & $\begin{array}{l}\text { Low } \\
\text { urgency }\end{array}$ & Urgent & $\begin{array}{l}\text { Very } \\
\text { urgent }\end{array}$ & $\begin{array}{c}\text { Extremely } \\
\text { urgent }\end{array}$ & Total \\
\hline $\begin{array}{l}\text { Lack of structured } \\
\text { buying process }\end{array}$ & $48 \%$ & $5 \%$ & $24 \%$ & $10 \%$ & $14 \%$ & $100 \%$ \\
\hline $\begin{array}{l}\text { Deficient stock } \\
\text { management }\end{array}$ & $29 \%$ & $14 \%$ & $19 \%$ & $19 \%$ & $19 \%$ & $100 \%$ \\
\hline $\begin{array}{l}\text { Faulty internal } \\
\text { communication }\end{array}$ & $52 \%$ & $14 \%$ & $14 \%$ & $10 \%$ & $10 \%$ & $100 \%$ \\
\hline $\begin{array}{l}\text { Lack of } \\
\text { management } \\
\text { flexibility }\end{array}$ & $43 \%$ & $19 \%$ & $14 \%$ & $10 \%$ & $14 \%$ & $100 \%$ \\
\hline $\begin{array}{l}\text { Low cooperation } \\
\text { between } \\
\text { companies }\end{array}$ & $29 \%$ & $5 \%$ & $33 \%$ & $10 \%$ & $24 \%$ & $100 \%$ \\
\hline $\begin{array}{l}\text { Low availability } \\
\text { of parts and } \\
\text { equipments }\end{array}$ & $33 \%$ & $5 \%$ & $19 \%$ & $14 \%$ & $29 \%$ & $100 \%$ \\
\hline $\begin{array}{l}\text { Deficiency in the } \\
\text { infraestructure } \\
\text { and accessibility } \\
\text { to the Pole }\end{array}$ & $38 \%$ & $14 \%$ & $24 \%$ & $10 \%$ & $14 \%$ & $100 \%$ \\
\hline $\begin{array}{l}\text { Increase of the } \\
\text { demand for } \\
\text { imported parts }\end{array}$ & $48 \%$ & $24 \%$ & $10 \%$ & $10 \%$ & $10 \%$ & $100 \%$ \\
\hline
\end{tabular}

Source: Author's elaboration.

Table 6

Frequency of the answers regarding the aspect of tendency

\begin{tabular}{|c|c|c|c|c|c|c|}
\hline \multirow{2}{*}{ Problems } & \multicolumn{6}{|c|}{ Tendency aspect } \\
\hline & $\begin{array}{l}\text { Without tendency } \\
\text { of worsening }\end{array}$ & $\begin{array}{l}\text { Will worsen in } \\
\text { a long-term }\end{array}$ & $\begin{array}{l}\text { Will worsen in } \\
\text { a medium-term }\end{array}$ & $\begin{array}{l}\text { Will worsen in } \\
\text { a short-term }\end{array}$ & $\begin{array}{l}\text { Will worsen } \\
\text { immediately }\end{array}$ & Total \\
\hline Lack of structured buying process & $43 \%$ & $14 \%$ & $24 \%$ & $14 \%$ & $5 \%$ & $100 \%$ \\
\hline Deficient stock management & $38 \%$ & $19 \%$ & $14 \%$ & $24 \%$ & $5 \%$ & $100 \%$ \\
\hline Faulty internal communication & $52 \%$ & $10 \%$ & $19 \%$ & $14 \%$ & $5 \%$ & $100 \%$ \\
\hline Lack of management flexibility & $43 \%$ & $24 \%$ & $24 \%$ & $5 \%$ & $5 \%$ & $100 \%$ \\
\hline Low cooperation between companies & $24 \%$ & $33 \%$ & $19 \%$ & $5 \%$ & $19 \%$ & $100 \%$ \\
\hline Low availability of parts and equipments & $38 \%$ & $10 \%$ & $14 \%$ & $24 \%$ & $14 \%$ & $100 \%$ \\
\hline Deficiency in the infraestructure and accessibility to the Pole & $24 \%$ & $33 \%$ & $24 \%$ & $5 \%$ & $14 \%$ & $100 \%$ \\
\hline Increase of the demand for imported parts & $48 \%$ & $19 \%$ & $19 \%$ & $5 \%$ & $10 \%$ & $100 \%$ \\
\hline
\end{tabular}

Source: Author's elaboration.

The Table 6 presents a quite similar pattern as the one found in Table 5. There is also a concentration in the left side of the table in terms of frequency of answers regarding the aspect of tendency of the problems listed. Except the 2 problems (deficient stock management and low availability of parts and equipments), all the other 6 problems present a frequency lower than $20 \%$ on the levels 4 and 5 of the table ("will worsen in a short-term" and "will worsen immediately" respectively).

Analyzing the three tables from a general perspective, it is possible to see what Terence and Filho (2001) mentioned as a behavioral aspect associated with conservatism, because most of the answer tend to shift to the left side of the tables, where there are the most soft or less important characteristics regarding each aspect. However, an affirmation cannot be done if this pattern occurs due to the real situation of the organizations inside the local productive system or by the fact that the respondents have a narrow view regarding strategy or management. 
4.3.3. RESUlTS REGARDING THE ASPECTS OF SEVERITY, URGENCY AND TENDENCY

The results regarding the severity of the problems are shown in the Table 7, which are related directly with the intensity level that a problem might affect an organization if it is not solved.
The Table 8 presents the results of the questionnaire related to the aspect of urgency of each listed problem that it is relative to the foreseen time that a problem might occur and turn into something severe according to the previous severity assessment.

Table 7

Results regarding the aspect of severity

\begin{tabular}{|c|c|c|c|c|c|c|c|}
\hline \multirow[b]{2}{*}{ Problems } & \multicolumn{5}{|c|}{ Severity aspect } & \multirow{2}{*}{$\begin{array}{c}\text { Total } \\
\text { answers }\end{array}$} & \multirow{2}{*}{$\begin{array}{r}\text { Weighted } \\
\text { average }(\mu)\end{array}$} \\
\hline & $\begin{array}{c}\text { Without } \\
\text { severity (1) }\end{array}$ & $\begin{array}{c}\text { Low } \\
\text { severity (2) }\end{array}$ & $\begin{array}{l}\text { Severe } \\
\text { (3) }\end{array}$ & $\begin{array}{c}\text { Very } \\
\text { severe (4) }\end{array}$ & $\begin{array}{l}\text { Extremely } \\
\text { severe (5) }\end{array}$ & & \\
\hline Lack of structured buying process & 8 & 3 & 4 & 2 & 4 & 21 & 2.57 \\
\hline Deficient stock management & 6 & 4 & 2 & 4 & 5 & 21 & 2.90 \\
\hline Faulty internal communication & 11 & 0 & 6 & 1 & 3 & 21 & 2.29 \\
\hline Lack of management flexibility & 9 & 4 & 4 & 0 & 4 & 21 & 2.33 \\
\hline Low cooperation between companies & 5 & 3 & 5 & 2 & 6 & 21 & 3.05 \\
\hline Low availability of parts and equipments & 7 & 2 & 5 & 1 & 6 & 21 & 2.86 \\
\hline Deficiency in the infraestructure and accessibility to the Pole & 7 & 3 & 2 & 3 & 6 & 21 & 2.90 \\
\hline Increase of the demand for imported parts & 10 & 5 & 2 & 0 & 4 & 21 & 2.19 \\
\hline
\end{tabular}

Source: Author's elaboration.

Table 8

Results regarding the aspect of urgency

\begin{tabular}{|c|c|c|c|c|c|c|c|}
\hline \multirow{2}{*}{ Problems } & \multicolumn{5}{|c|}{ Urgency Aspect } & \multirow{2}{*}{$\begin{array}{c}\text { Total } \\
\text { answers }\end{array}$} & \multirow{2}{*}{$\begin{array}{c}\text { Weighted } \\
\text { average }(\mu)\end{array}$} \\
\hline & $\begin{array}{l}\text { Without } \\
\text { urgency (1) }\end{array}$ & $\begin{array}{c}\text { Low } \\
\text { urgency (2) }\end{array}$ & $\begin{array}{l}\text { Urgent } \\
\text { (3) }\end{array}$ & $\begin{array}{c}\text { Very } \\
\text { urgent (4) }\end{array}$ & $\begin{array}{l}\text { Extremely } \\
\text { urgent (5) }\end{array}$ & & \\
\hline Lack of structured buying process & 10 & 1 & 5 & 2 & 3 & 21 & 2.38 \\
\hline Deficient stock management & 6 & 3 & 4 & 4 & 4 & 21 & 2.86 \\
\hline Faulty internal communication & 11 & 3 & 3 & 2 & 2 & 21 & 2.10 \\
\hline Lack of management flexibility & 9 & 4 & 3 & 2 & 3 & 21 & 2.33 \\
\hline Low cooperation between companies & 6 & 1 & 7 & 2 & 5 & 21 & 2.95 \\
\hline Low availability of parts and equipments & 7 & 1 & 4 & 3 & 6 & 21 & 3.00 \\
\hline Deficiency in the infraestructure and accessibility to the Pole & 8 & 3 & 5 & 2 & 3 & 21 & 2.48 \\
\hline Increase of the demand for imported parts & 10 & 5 & 2 & 2 & 2 & 21 & 2.10 \\
\hline
\end{tabular}

Source: Author's elaboration.

Table 9

Results regarding the aspect of tendency

\begin{tabular}{|c|c|c|c|c|c|c|c|}
\hline \multirow[b]{2}{*}{ Problems } & \multicolumn{5}{|c|}{ Tendency aspect } & \multirow[b]{2}{*}{$\begin{array}{c}\text { Total } \\
\text { answers }\end{array}$} & \multirow[b]{2}{*}{$\begin{array}{c}\text { Weighted } \\
\text { average } \\
(\mu)\end{array}$} \\
\hline & $\begin{array}{c}\text { Without } \\
\text { tendency of } \\
\text { worsening (1) }\end{array}$ & $\begin{array}{l}\text { Will worsen } \\
\text { in a long- } \\
\text { term (2) }\end{array}$ & $\begin{array}{l}\text { Will worsen } \\
\text { in a medium- } \\
\text { term (3) }\end{array}$ & $\begin{array}{l}\text { Will worsen } \\
\text { in a short- } \\
\text { term (4) }\end{array}$ & $\begin{array}{c}\text { Will worsen } \\
\text { immediately } \\
\text { (5) }\end{array}$ & & \\
\hline Lack of structured buying process & 9 & 3 & 5 & 3 & 1 & 21 & 2.24 \\
\hline Deficient stock management & 8 & 4 & 3 & 5 & 1 & 21 & 2.38 \\
\hline Faulty internal communication & 11 & 2 & 4 & 3 & 1 & 21 & 2.10 \\
\hline Lack of management flexibility & 9 & 5 & 5 & 1 & 1 & 21 & 2.05 \\
\hline Low cooperation between companies & 5 & 7 & 4 & 1 & 4 & 21 & 2.62 \\
\hline Low availability of parts and equipments & 8 & 2 & 3 & 5 & 3 & 21 & 2.67 \\
\hline $\begin{array}{l}\text { Deficiency in the infraestructure and accessibility to the } \\
\text { Pole }\end{array}$ & 5 & 7 & 5 & 1 & 3 & 21 & 2.52 \\
\hline Increase of the demand for imported parts & 10 & 4 & 4 & 1 & 2 & 21 & 2.10 \\
\hline
\end{tabular}

Source: Author's elaboration. 
It can be seen in the Table 9 the results obtained regarding the aspects of tendency, that means the propensity a problem has to develop if nothing is done to solve them or the propensity of the damages considered during the severity assessment.

Table 10

GUT matrix

\begin{tabular}{|c|c|c|c|c|c|c|}
\hline Number & Problems & Severity & Urgency & Tendency & Prioritization Level (GxUxT) & Priority \\
\hline 1 & Lack of structured buying process & 2.57 & 2.38 & 2.24 & 13.70 & $5^{\circ}$ \\
\hline 2 & Deficient stock management & 2.90 & 2.86 & 2.38 & 19.76 & $3^{\circ}$ \\
\hline 3 & Faulty internal communication & 2.29 & 2.10 & 2.10 & 10.03 & $7^{\circ}$ \\
\hline 4 & Lack of management flexibility & 2.33 & 2.33 & 2.05 & 11.15 & $6^{\circ}$ \\
\hline 5 & Low cooperation between companies & 3.05 & 2.95 & 2.62 & 23.57 & $1^{\circ}$ \\
\hline 6 & Low availability of parts and equipments & 2.86 & 3.00 & 2.67 & 22.86 & $2^{\circ}$ \\
\hline 7 & Deficiency in the infraestructure and accessibility to the Pole & 2.90 & 2.48 & 2.52 & 18.15 & $4^{\mathrm{o}}$ \\
\hline 8 & Increase of the demand for imported parts & 2.19 & 2.10 & 2.10 & 9.62 & $8^{\circ}$ \\
\hline
\end{tabular}

Source: Author's elaboration.

The Tables 7, 8, and 9 will have their results grouped and manipulated to elaborate the GUT matrix. The final grade of each aspect was attributed after the application of all questionnaires and acquisition of the final score utilizing the described methodology, enabling the Priority Level (PL) result of each problem listed as shown in the Table 10.

Following the guidance of Meireles (2001) about how to define priorities to alternatives of action, this research list the 5 problems considered most urgent in terms of the PL found on the matrix, in descending order:

1. Low cooperation between companies;

2. Low availability of parts and equipments;

3. Deficient stock management;

4. Deficiency in the infrastructure and accessibility to the Pole;

5. Lack of a structured buying process.

Among the problems listed, 3 are internal to the organizations (problems number 2, 3 and 5), they are related to the operational routine of the studied companies, while the other 2 are external (problems number 1 and 4), involving the arrangement environment as a whole and the role of these organizations inside the environment. This way, to achieve a better result on the problems found, it is expected that the companies focus their efforts on their management and improvement of their internal operational processes, while the external problems should be directed to the entity responsible for the arrangement.

\subsubsection{ACtions PROPOSED AND IMPROVEMENTS SUGGESTED}

Based on the internal and external analysis of the organizations and the results obtained with the GUT matrix, improvements and a few actions are suggested taking into consideration the organizations as an individual and the Association as the entity responsible for the management of the local productive system.

The first approaching perspectives which the SBCs can address, in other words, they can act upon actively, trace action plans and define clear objectives that might be reach within a stipulated time. The second is a responsibility of the Association of the Automotive pole, because it has representativeness and resources to deal with broader issues that involve the Pole's infrastructure and its surroundings. Regarding the organizations individually, the following actions are listed:

- Increase the partnerships and cooperations between local companies, consequently increasing the information exchange, sharing clients and solving problems together, as a solution for the problem 1. Even though it was identified as an external problem, the change of attitude and understanding of the benefits of this action should come from the managers inside the organizations;

- Identify any shortage in the mix of products and equipments offered, searching and exploring partnerships with secondary suppliers to not suffer from a possible fall of the availability of determined products and equipments in the market, as a solution of the problem 2 ;

- Improvement of the operational process, focusing on the deficient stock management and structuring a buying process, reducing costs through the realization of structured and orderly buys avoind parts and equipments losses because of the lack of stock control, as a solution for the problems 3 and 5.

Regarding the Association of the Automotive pole, improvements are proposed where the first two solutions are presented for the problem 4 and the last one, as a suggestion to correct a deficiency found in the organizations individually but that could be addressed by the Association:

- Better coordination and raising of resources along with the Government to obtain gains in terms of accessibility to the Pole and urban improvements, in terms of cleansing and extension of the parking lots, bringing a higher valuation of the local productive system;

- Improvement of the infrastructure in terms of signaling, lighting, sewage and pluvial network and new parking lots areas;

- Creation of a qualification program for the managers, entrepreneurs and owners to qualify them in terms of quality business management.

The actions proposed corroborate for what is mentioned by Oliveira et al. (2001), in relation to creating circumstances fa- 
vorabel to the performance, since they will help to correct a few failures existent in the arrangement, enabling them to be identified, classified and helping the development process to be given in an organized and sustainable way. It's necessary to emphasize the importance of some of the actions recommended to the entrepreneurs of productive system. Such initiatives align with the demands of the globalized world, as cited by Batista and Santos (2015) and Carrol and Helfert (2015), forcing organizations to invest in competitiveness and continuous improvement.

It identifies infrastructure and organizational problems cited by Kalkman and Waard (2017), and it is recommended to increase partnerships and cooperation between companies, action proposed to the solution of the "Low cooperation between companies" problem, with the highest PL. In addition to raise the interaction level between the companies, will also boost the innovation and interactive learning, cited by Camisón and Villar-López (2014), through a greater generation of information regarding the processes, products, management and services of the organizations studied, enabling a better experiences exchange and the appearance of new ideas nourishing their growth.

It is also observed the demands for articulation to capture resources and infrastructure improvement, cited by Rodríguez et al. (2016) and Kalkman and Waard (2017) as a way of solving the problem of "Infrastructure and accessibility to the Pole". In addition to solve the exposed problem, it will also increase the recognition and representativeness of the Association in front of the companies inserted in the Pole, making possible the gradual implementation of a formal governance, and integration like cited by Barros and Moreira (2006) and Ribeiro et al. (2020).

\section{CONCLUSION}

The main objective of this work is to present an explanatory study of the environment of the small companies inserted in the Automotive Pole of Nova Iguaçu, using strategic tools (SWOT analysis and GUT matrix) to perform the analysis and provide improvement suggestions and propose actions implementation to SBCs.

Regarding the specific objectives, the observations combined with the interview made possible the identification and characterization of the arrangement. The SWOT analysis and GUT matrix were used to analyze and find the criticality level of the deficiencies of the arrangement and its organizations, for example, the low level of cooperation between, considered the most severe, as well as to define the priority order of the following problems: availability of parts and equipments, stock management, infrastructure and accessibility to the Pole and buying process, that were mentione in the actions definition and improvements suggested.

The innovation method of prioritizing problems through the GUT matrix presents advantages, because it does not require broad managerial vision or experience in the different areas of the company, it manages to capture a perception of criticality that does not detract from the veracity of the information collected.

It was possible to conclude that "not planning" makes difficult the identification of opportunities, needs and threats and consequently to define measures that might help in the conduction of the bussiness seizing opportunities and mitigating difficulties. For this reason, it is fundamental that companies get involved and have a deeply knowledge of the external environment which they are inserted, and also keep their internal environment healthy and sustainable.

For future studies, it is proposed to study the strategic planning and application of the GUT strategic tool in other municipalities, treating and prioritizing the population demands in terms of public services as a way to guide the political decision-maker on how to direct resources and infrastructure, mainly in peripheral regions where populations are very poor.

\section{REFERENCES}

Ahadi, S., and Kasraie, S. (2020). Contextual factors of entrepreneurship intention in manufacturing SMEs: the case study of Iran. Journal of Small Business and Enterprise Development, 27(4), 633-657. https:// doi.org/10.1108/JSBED-02-2019-0074

Babalola, F. D., and Jegede, E. B. (2020). Participation of stakeholders in sustainable management of a state-owned forest reserve in kwara state, nigeria. Revista Produção e Desenvolvimento, 6. https://doi. org/10.32358/rpd.2020.v6.504

Barros, F.S.O., and Moreira, M.V.C. (2006). O Capital Social nas Aglomerações Produtivas de Micro e Pequenas Empresas: Estudo de um Arranjo Produtivo Turístico. Organizações \& Sociedade, 13(39), 113-130. https://doi.org/10.1590/S1984-92302006000400007

Batista, I.C.P., and Santos, M.G.F. (2015). O Impacto Financeiro das Auditorias da Qualidade nas empresas Portuguesas. Revista Produção e Desenvolvimento, 1(3), 90-102. https://doi.org/10.32358/rpd.2015. v1.112

Behr, A., Moro, E. L. S., and Estabel, L. B. (2008). Gestão da biblioteca escolar: metodologias, enfoques e aplicação de ferramentas de gestão e serviços de biblioteca. Ciência da Informação, 37(2), 32-42. https://doi.org/10.1590/S0100-19652008000200003

Bezerra, G. J., and Schlindwein, M. M. (2017). Agricultura familiar como geração de renda e desenvolvimento local: uma análise para Dourados, MS, Brasil. Interações (Campo Grande), 18(1), 3-15.

Cabrera, L.C., Schultz, G., and Talamini, E. (2017). Limites e oportunidades para a construção de um Arranjo Produtivo Local (APL): a experiência do projeto Balde Cheio em Mato Grosso do Sul. Interações (Campo Grande), 18(4), 19-30. https://doi.org/10.20435/ inter.v18i4.1484

Camisón, C., and Villar-López, A. (2014). Organizational innovation as an enabler of technological innovation capabilities and firm performance. Journal of business research, 67(1), 2891-2902.

Carrol, N., and Helfert, M. (2015). Service capabilities within open innovation revisiting the applicability of capability maturity models. Journal of Enterprise Information Management, 28(2), 275-303.

Carvalho, C. P., and Castro, C. F. (2020). Application of a tool based on the GUT matrix for the improvement of quality Indicators in the automotive industry. World Journal of Advanced Engineering Technology and Sciences, 1(1), 037-043. https://doi.org/10.30574/ wjaets.2020.1.1.0022

Carvalho, L., Rambo, A. G., and Stoffel, J. (2020). Agroecological territorial dynamics: considerations about brazilian settlements. Revista Produção e Desenvolvimento, 6. https://doi.org/10.32358/rpd.2020.v6.480

Ceretta, S.B.N., and Froemming, L.M.S. (2015). City Marketing: dimensões importantes para uma cidade de bem viver. Revista Produção e Desenvolvimento, 1(3), 67-79. https://doi.org/10.32358/ rpd.2015.v1.107

Costa, A. R. S., Santos, T. C. G., Kozmhinsky, M., de Alencar, S. K. R. P., and Valle, G. (2017). Aplicação da matriz GUT na gestão integrada de resíduos sólidos da cidade do Recife-PE. Revista AIDIS de Inge- 
niería y Ciencias Ambientales. Investigación, desarrollo y práctica, 10(2), 201-213.

Damazio, M. M., Aquilano, N. J., and Chase, R. B. (2001). Fundamentos da Administração. Porto Alegre: Artmed.

Daychouw, M. (2007). 40 Ferramentas e Técnicas de Gerenciamento. Rio de Janeiro: Brasport.

Eberhart, R.N., Eesley, C.E., and Eisenhardt, K.M. (2017). Failure is an option: Institutional change, entrepreneurial risk, and new firm growth. Organization Science, 28(1), 93-112. https://doi.org/10.1287/ orsc. 2017.1110

Galindo, A.G., Câmara, S.F., and Lopes Junior, E.P. (2011). Identificação dos desafios do Arranjo Produtivo Local de Tecnologia da Informação de Fortaleza-CE. Organizações \& Sociedade, 18(57), 265-283. https://doi.org/10.1590/S1984-92302011000200004

Gomes, S. C., Negrão, K. R. M., Carvalho, M. C. S., and Cabral, E. R. (2016). Índice de Desempenho Competitivo das empresas do Arranjo Produtivo Local embrionário de Cerâmica Vermelha na Região do Carajás/PA. Espacios, 37(24), 27.

Halili, Z. (2020). Identifying and ranking appropriate strategies for effective technology transfer in the automotive industry: Evidence from Iran. Technology in Society, 62, 101264. https://doi.org/10.1016/j. techsoc.2020.101264

Hartmann, A.M. (2016). Strategic Options for MNEs Operating in Emerging Markets. In: Multinational Enterprise Management Strategies in Developing Countries. IGI Global, 34-49. https://doi. org/10.4018/978-1-5225-0276-0.ch002

Ivo, G.A., Cruz, D.B.F., Chinelato, and F.B., Ziviani, F. (2016). A expansão do crédito no Brasil: uma ferramenta para o desenvolvimento socioeconômico. Gestão \& Regionalidade, 32(95), 160-174. https://doi.org/10.13037/gr.vol32n95.3357

Jacometti, M., Castro, M.D., Gonçalves, S.A., and Costa, M.C. (2016). Análise de efetividade das políticas públicas de Arranjo Produtivo Local para o desenvolvimento local a partir da teoria institucional. Revista de Administração Pública, 50(3), 425-454. https://doi. org/10.1590/0034-7612142712

Kalkman, J.P., and Waard, E.J. (2017). Inter-organizational disaster management projects: finding the middle way between trust and control. International Journal of Project Management, 35(5), 889-899. https://doi.org/10.1016/j.ijproman.2016.09.013

Kepner, C., and Tregoe, B. (1981). O Administrador Racional. São Paulo: Atlas.

Leal, D., Queiroz, D. T. de, and Rodrigues, R. A. (2020). A behavior analysis of brazilian farmers based on sunk cost effects and prospect theory. Revista Produção e Desenvolvimento, 6. https://doi. org/10.32358/rpd.2020.v6.473

Lima, A.C.C., and Martini, R.A. (2016). O Plano Real e a adoção da política de metas de inflação no Brasil: uma análise baseada no Novo Consenso Macroeconômico. Revista Debate Econômico, 4(1), 4-30.
Marshall Junior, I., Alves, C.A., and Varanda, R.A. (2006). Gestão da Qualidade. 8.ed. Rio de Janeiro: FGV.

Meireles, M. (2001). Ferramentas administrativas para identificar, observar e analisar problemas. Organizações com foco no cliente. São Paulo: Arte \& Ciência.

Miao, C., Qian, S. and Ma, D. (2017). The Relationship between Entrepreneurial Self-Efficacy and Firm Performance: A Meta-Analysis of Main and Moderator Effects. Journal of Small Business Management, 55(1), 87-107. https://doi.org/10.1111/jsbm.12240

Oliveira, D.P.R. (2015). Planejamento estratégico: conceitos, metodologia e práticas (33 ed.). São Paulo: Atlas.

Oliveira, L. L. M., Pedro Filho, F.S., Madeira, M. J. A., and Melo, J. V. (2017). Innovating with the matrix gut applied in one platform of services. European Journal of Business and Social Sciences, 5(10), 65-75.

Ribeiro, L. L., Silva, S. F., and Pimenta, M. L. (2020). Cross-Functional Integration at Agribusiness Brazilian Organizations. Revista Produção e Desenvolvimento, 6. https://doi.org/10.32358/rpd.2020. v6.403

Rodríguez, J. A., Giménez, C., and Arenas, D. (2016). Cooperative initiatives with NGOs in socially sustainable supply chains: How is inter-organizational fit achieved?. Journal of Cleaner Production, 137, 516-526. https://doi.org/10.1016/j.jclepro.2016.07.115

Rolleri, M., Nadim, A., Lussier, R. (2016). Improving Small Business Viability Through the Strategic Longevity and Health Maintenance Evaluation. Small Business Institute Journal, 12(1), 10.

Silva, A. A., Silva, N. S., Barbosa, V. A., and Baptista, J. A. (2011). A Utilização da Matriz SWOT como Ferramenta Estratégica - Um Estudo de Caso em uma Escola de Idioma de São Paulo. In Anais do VIII Simpósio de Excelência em Gestão e Tecnologia.

Silva, A. S., Medeiros, C. F., and Vieira, R. K. (2017). Cleaner Production and PDCA cycle: Practical application for reducing the Cans Loss Index in a beverage company. Journal of cleaner production, 150, 324-338. https://doi.org/10.1016/j.jclepro.2017.03.033

Silva, M. L., Santos Cobas, N. L. de los, Matta, I. B., and Juliani, L. I. (2020). Production strategies of a dairy industry in Uruguay. Revista Produção e Desenvolvimento, 6. https://doi.org/10.32358/rpd.2020. v6.439

Souza, W., and Qualharini, E. (2007). O Planejamento Estratégico nas Micro e Pequenas Empresas. Workshop de Gestão Integrada: Riscos e Desafios. São Paulo: Centro Universitário Senac.

Szum, K., and Nazarko, J. (2020). Exploring the determinants of Industry 4.0 development using an extended SWOT analysis: A regional study. Energies, 13(22), 5972. https://doi.org/10.3390/en13225972

Terence, A. C. F., and Filho, E. E. (2001). As Particularidades das Pequenas Empresas no Planejamento Estratégico: A Elaboração de um Roteiro Prático. In Anais do II EGEPE, Londrina, Paraná.

Vergara, S. C. (2010). Projetos e Relatórios de Pesquisa em Administração. São Paulo: Atlas. 
